Article

\title{
In Vitro Estimation of the Effect of Grinding on Rumen Fermentation of Fibrous Feeds
}

\author{
Ignacio Rubén Ortolani, Zahia Amanzougarene and Manuel Fondevila *
}

Departamento de Producción Animal y Ciencia de los Alimentos, Instituto Agroalimentario de Aragón (IA2), Universidad de Zaragoza-CITA, M. Servet 177, 50013 Zaragoza, Spain; nacho_ortolani@hotmail.com (I.R.O.); zahiaagro@yahoo.fr (Z.A.)

* Correspondence: mfonde@unizar.es; Tel.: +34-876554171

Received: 24 March 2020; Accepted: 21 April 2020; Published: 23 April 2020

Simple Summary: Intensive feeding systems for beef production are based on high proportions of concentrate at the expense of forages, which can lead to digestive disorders. However, the particle size of the different fibrous feeds can also affect the rumen fermentation pattern, and thus animal performance. Fermentation of six fiber sources (soybean hulls, sugarbeet pulp, palm kernel cake, oat hulls, dehydrated alfalfa meal, and barley straw) in two presentation forms (non-processed and ground) was studied in a closed batch in vitro system. Higher gas production was recorded when substrates were presented in ground form, except for barley straw; however, substrates ranked in the same order irrespective of their presentation form. The particle size did not markedly affect volatile fatty acids proportions. Methane production as an index of fermentation efficiency did not show major differences between feed presentation forms, or non-forage substrates as compared with straw and is related more with the magnitude of fermentation than with qualitative changes in fermentation. Considering other feed components, the comparison of substrates on rumen microbial fermentation depends not only on their fiber proportion but can also be mediated by their levels of protein and fat.

\begin{abstract}
The fermentation patterns of six fiber sources, soybean hulls ( $\mathrm{SH})$, sugarbeet pulp (BP), palm kernel cake (PK), oat hulls (OH), dehydrated alfalfa meal (DA), and barley straw (BS) were evaluated for this study on the effect of their presentation form (non-processed, NP and ground, GR). Substrates were tested in a conventional in vitro batch system, using rumen fluid obtained from ewes fed 0.5 alfalfa hay and 0.5 barley straw. All substrates rendered a higher gas production in GR form $(p<0.05)$ except for BS but ranked similarly irrespective of the presentation form. Among the substrates, when incubated NP, the highest volume of gas was recorded with BP from $8 \mathrm{~h}$ onwards $(p<0.05)$, whereas $\mathrm{OH}$ and BS resulted in the lowest gas volume $(p<0.05)$. During the first half of the incubation period, methane production was higher in GR than NP $(p<0.05)$. Among substrates, despite NP or GR, methane production with BP was the highest $(p<0.05)$. Similarly, the presentation form did not qualitatively affect fermentation, as no differences were observed in volatile fatty acids proportions. The effect of particle size of fibrous substrates does not have a major impact on the rate and extent of the rumen microbial fermentation.
\end{abstract}

Keywords: in vitro fermentation pattern; fibrous sources; non-processed; ground; gas production

\section{Introduction}

Beef cattle feeding in the Mediterranean countries is generally based on the use of high proportions of concentrate feeds, plus cereal straw given in long form. Concentrate and straw are offered separately, and both given ad libitum, reaching proportions of around 90:10 concentrate to straw ratio [1-3], in order to reach high animal performance. Under such circumstances, the role of straw as a 
fibrous source is to maintain a functional rumen environment, although there is a risk of subclinical acidosis and other digestive disorders [4]. The effect of long fiber on the enhancement of mastication, rumination, and salivation [5,6] complements that of dietary proportion of fiber, promoting a healthier rumen environment.

Straw costs are high as its management requires high labor, space availability, and inefficient transport, so other fibrous alternatives have been recently considered. The inclusion of agro-industrial fibrous by-products, with similar proportions of either insoluble (cellulose, hemicelluloses) or soluble (mostly pectin) polysaccharides as forages [7], offered together with the concentrate as a total mixed ration has been proposed as a way to reduce such inconveniences. Non-forage fiber sources are heterogeneous and widely variable in cell wall proportion and composition, as well as in physical characteristics $[6,8]$. Therefore, their smaller particle size can limit their role as effective fiber in the rumen. Some fibrous by-products can have a particle size over $1.18 \mathrm{~mm}$, which has been considered to be a limiting size for enhancing mastication effect [9], although Yang and Beauchemin [10] found that this effect was promoted by fibrous particles over $8 \mathrm{~mm}$. Recent studies have approached the potential of small particle size fiber sources as forage substitutes [11], and Iraia et al. [12] found that rumen $\mathrm{pH}$ and time of mastication and rumination were not correlated with particle size of dietary fibrous feeds.

Despite the effects on animal feeding behavior, particle size has been positively correlated with neutral detergent fiber (NDF) digestibility, associated with higher chewing time, rumen $\mathrm{pH}$, and acetate to propionate ratio [13], although the contrary [14] or no effect [15] have also been reported. In contrast, a smaller particle size should increase microbial access, and thus the rate, although not the extent, of fermentation [16]. Alternatively, a higher fermentation efficiency in terms of lower methane production can be expected when forages are substituted with increasing levels of small particle size by-products [17], partly because of a reduction in acetate proportion and an increased rate of passage of concentrate particles [18].

The in vivo study of responses in rumen fermentation is labor and cost expensive, and it is difficult to differentiate the rate and extent of fiber fermentation from those effects related to animal feeding behavior, such as intake, rate of passage, or salivation. In contrast, in vitro studies can be useful to mimic the fermentation pattern of substrates independently and under controlled conditions, allowing the estimation of digestion kinetics of a single feed [19]. However, as a standardization compromise, feeds are generally incubated ground to $1 \mathrm{~mm}$ size [16,20], and thus the in vitro study of particle size effect is seldom considered.

Therefore, this work aimed to study the effect of grinding, on in vitro microbial fermentation, to reduce the particle size of several fibrous substrates differing in their cell wall proportion and composition by comparing them to their natural (non-processed) presentation form in relation to ground to $1 \mathrm{~mm}$ particle size, considering cereal straw in long form $(20 \mathrm{~mm})$ as a standard feed.

\section{Materials and Methods}

\subsection{Substrates and Inocula}

The following six fiber sources were chosen as substrates for comparison: soybean hulls (SH), sugarbeet pulp (BP), palm kernel cake (PK), oat hulls (OH), dehydrated alfalfa meal (DA), and barley straw (BS). Chemical composition and particle size distribution are given in Table 1. For incubation purposes, BS was manually cut into particles of around $20 \mathrm{~mm}$ length, simulating forage intake in ruminants. A subsample of each substrate was ground in a hammer mill (Retsch Gmbh/SK1/417449, Haan, Germany) through a sieve of $1 \mathrm{~mm}$.

Rumen fluid was obtained from four adult ewes $(54.5 \pm 6.8 \mathrm{~kg}$ live weight) housed in the facilities of the Servicio de Apoyo a la Experimentación Animal of the Universidad de Zaragoza. From three weeks before the experiment, donor animals were daily given $1000 \mathrm{~g}$ of a 1:1 forage (0.5 alfalfa hay and 0.5 barley straw) to concentrate ( 0.6 barley grain, 0.20 maize grain, and 0.20 soybean meal) diet, in a single offer at 09:00. On each incubation run, rumen contents (approximately $300 \mathrm{~mL}$ ) of each animal 
were sampled before feeding and filtered through a cheesecloth. Then, contents from the four animals were mixed, dispensed in thermos flasks, and immediately transferred to the lab for incubation.

Table 1. Chemical composition ( $\mathrm{g} / \mathrm{kg} \mathrm{DM})$ and particle size (proportion of particles below a specific size and average size, $\mathrm{mm}$ ) of feeds used as incubation substrates.

\begin{tabular}{ccccccc}
\hline Component & SH & BP & PK & OH & DA & BS \\
\hline Chemical composition & & & & & & \\
OM & 946 & 920 & 962 & 953 & 886 & 872 \\
CP & 179 & 85 & 157 & 48 & 133 & 61 \\
EE & 18 & 3 & 88 & 11 & 18 & 13 \\
aNDFom & 592 & 442 & 555 & 771 & 513 & 760 \\
ADF & 417 & 234 & 352 & 376 & 343 & 434 \\
ADL & 16 & 23 & 87 & 56 & 66 & 40 \\
Particle size & & & & & & \\
$<0.15 \mathrm{~mm}$ & 0.03 & 0.02 & 0.05 & 0.05 & 0.12 & - \\
$0.15-0.30 \mathrm{~mm}$ & 0.02 & 0.01 & 0.06 & 0.02 & 0.19 & - \\
$0.30-0.60 \mathrm{~mm}$ & 0.08 & 0.05 & 0.25 & 0.03 & 0.32 & - \\
$0.60-1.20 \mathrm{~mm}$ & 0.27 & 0.15 & 0.18 & 0.09 & 0.27 & - \\
$1.20-2.00 \mathrm{~mm}$ & 0.36 & 0.77 & 0.46 & 0.11 & 0.10 & - \\
$>2.00 \mathrm{~mm}$ & 0.24 & 0.00 & 0.00 & 0.68 & 0.00 & - \\
average size & 1.89 & 1.77 & 1.32 & 5.83 & 0.83 &
\end{tabular}

SH, soybean hulls; BP, sugarbeet pulp; PK, palm kernel meal; OH, oat hulls; DA, dehydrated alfalfa meal; BS, barley straw; DM, dry matter; OM: organic matter; $\mathrm{CP}$, crude protein; $\mathrm{EE}$, ether extract; aNDFom, neutral detergent fiber; ADF, acid detergent fiber; ADL, acid detergent lignin.

Animal care and procedures for extraction of rumen inoculum were approved by the Ethics Committee for Animal Experimentation (PI12/06). Care and management of animals agreed with the Spanish Policy for Animal Protection RD 53/2013, which complies with EU Directive 2010/63 on the protection of animals used for experimental and other scientific purposes.

\subsection{Experimental Procedures}

The six substrates were incubated in two presentation sizes: non-processed (NP) (as they are commercialized, except for BS that was cut to $20 \mathrm{~mm}$ ) and ground to $1 \mathrm{~mm}$ (GR). Four incubation runs $(48 \mathrm{~h})$ were carried out, following the Theodorou et al. [21] procedures, but without microminerals and resazurin [20], with 4 bottles per treatment, plus another 4 bottles without substrate as blanks of inoculum (total of 52 bottles per run). The concentration of bicarbonate buffer in the incubation solution was adjusted to obtain an incubation $\mathrm{pH}$ of 6.5, as in Amanzougarene and Fondevila [22]. Incubations were carried out for $48 \mathrm{~h}$ in a water bath at $39^{\circ} \mathrm{C}$. Two bottles per treatment were used to determine gas production, and the pressure was recorded at 2, 4, 6, 8, 10,12, 16, 24, 36, and $48 \mathrm{~h}$. After that time, the bottles were opened, their $\mathrm{pH}$ measured (CRISON micropH 2001, Barcelona, Spain) to validate incubation conditions, and the liquid medium sampled $(2 \mathrm{~mL}$ on $0.5 \mathrm{~mL}$ solution of $0.5 \mathrm{M}$ phosphoric acid with $1 \mathrm{mg}$ 4-methyl-valeric acid as internal standard) and stored at $-20^{\circ} \mathrm{C}$ until analysis of volatile fatty acid (VFA) concentration. The remaining content was filtered through nylon bags ( $45 \mu \mathrm{m}$ pore size) that were dried at $60^{\circ} \mathrm{C}$ for $48 \mathrm{~h}$ to determine organic matter disappearance (OMd).

Methane concentration in the gas produced was determined at 0 to $12 \mathrm{~h}, 12$ to $24 \mathrm{~h}, 24$ to $36 \mathrm{~h}$, and 36 to $48 \mathrm{~h}$ intervals, by a single sample $(5 \mathrm{~mL})$ of the gas produced in the whole interval. Gas samples for the 0 to $12 \mathrm{~h}$ and for 12 to $24 \mathrm{~h}$ intervals were collected from the third and fourth incubated bottles per treatment, whereas one of the two bottles used for gas production was used for gas sampling of the 24 to $36 \mathrm{~h}$ and 36 to $48 \mathrm{~h}$ intervals. Liquid medium from the bottle incubated for $12 \mathrm{~h}$ was also sampled for the analysis of VFA concentration. 


\subsection{Chemical and Physical Analyses}

Dry matter $(\mathrm{DM})$ and organic matter $(\mathrm{OM})$ contents in ground substrates and incubation residues were analyzed following the AOAC [23] procedures (methods ref. 934.01 and 942.05). Substrates were also analyzed for crude protein (CP) and ether extract (EE) (ref. 976.05 and 2003.05) [23], and their concentration of aNDFom was analyzed as described by Mertens [24] in an Ankom 200 Fibre Analyzer (Ankom Technology, New York, NY, USA), using $\alpha$-amylase and sodium sulphite, and results were expressed exclusive of residual ashes. The ADF (ref. 973.18) and ADL were determined as described by AOAC [23] and Robertson and Van Soest [25], respectively. The estimation of particle size in non-processed substrates was carried out by dry sieving. About $200 \mathrm{~g}$ DM of each sample were placed in a sieve shaker fitted with 2.00, 1.20, 0.60, 0.30, and $0.15 \mathrm{~mm}$ pore size sieves (Filtra Vibración, Badalona, Spain) and manually shaken in horizontal movements for $40 \mathrm{~min}$. After, sieves were weighed to determine the residual DM on each. For those substrates having particles retained by the $2 \mathrm{~mm}$ sieve $(\mathrm{OH}$ and $\mathrm{SH})$, the average particle size of such particles was measured under a dissecting microscope. The average particle size was calculated as the weighted mean for each substrate.

Pressure produced on each bottle was measured with a HD8804 manometer provided with a TP804 pressure gauge (Delta OHM, Caselle di Selvazzano, Italy). Readings corrected for the atmospheric pressure were converted to volume $(\mathrm{mL})$ using a pre-established linear regression $\left(\mathrm{n}=103, R^{2}=0.996\right)$ recorded in the same type of bottles and expressed per unit of incubated OM. Methane concentration was measured in an Agilent 6890 apparatus (Agilent Technologies, Madrid, Spain) equipped with a capillary column (HP-FFAP polyethylene glycol TPA, $30 \mathrm{~m} \times 530 \mu \mathrm{m}$ id), calibrated with a $10 \% \mathrm{CH}_{4}$ standard, with a flux of $2 \mathrm{~mL} / \mathrm{min}$ at $250^{\circ} \mathrm{C}$. The frozen samples of incubation medium were thawed and centrifuged at $13,000 \times g$ for $15 \mathrm{~min}$ at $4{ }^{\circ} \mathrm{C}$ for their analysis of VFA, which were determined by gas chromatography on the same apparatus than for methane analysis.

\subsection{Calculations and Statistical Analyses}

Results were analyzed statistically by ANOVA using the Statistix 10 package [26], considering the incubation series as a block. The effect of the nature of presentation $(n=2)$, the substrate $(n=6)$, and their interactions were studied as factors for each time of sampling. For total gas production and $\mathrm{OMd}$, the experimental unit was the average of the two bottles per treatment incubated in the same run, whereas for methane production and VFA pattern at $12 \mathrm{~h}$, values from a single bottle per run were considered. Treatment differences among means with $p<0.05$ and $0.05<p<0.10$ were accepted as representing statistically significant differences and a trend to differences, respectively. When significant, differences were contrasted by the Tukey $t$-test.

\section{Results}

Particle size distribution in NP substrates (Table 1) shows that a high proportion of $\mathrm{OH}$ and BP, and to a lower extent $\mathrm{SH}$, were over $1.20 \mathrm{~mm}(0.79,0.77$, and 0.60 , respectively). In contrast, 0.63 of DA particles were below $0.60 \mathrm{~mm}$, whereas PK had major proportions of particles lower than $0.60 \mathrm{~mm}$ and higher than $1.2 \mathrm{~mm}(0.36$ and 0.46$)$. BS was not considered in this estimation as it was cut to a fixed size of $20 \mathrm{~mm}$. Mean inoculum $\mathrm{pH}$ in the four incubation runs was $6.67 \pm 0.23$, and averaged 6.59 (from 6.34 to 6.70$), 6.53$ (6.38 to 6.65) and 6.50 (6.38 to 6.59) at 12, 24, and $48 \mathrm{~h}$.

The effect of the interaction presentation $\mathrm{x}$ substrate on gas production was significant from 6 to $48 \mathrm{~h}(p<0.05)$ and tended to be significant at $4 \mathrm{~h}(p=0.080)$. This highlights the higher gas production from BP incubated in GR form as compared with NP that was observed from 4 to $12 \mathrm{~h}(229 \mathrm{vs} .209 \mathrm{~mL} / \mathrm{g}$ $\mathrm{OM}$ at $12 \mathrm{~h}$ incubation) and the fact that all substrates produced more gas in ground form (significant effect of presentation form from 2 to $24 \mathrm{~h}, p<0.05$ ) except BS, that recorded numerically higher values when NP as compared with GR ( 47 vs. 38,99 vs. 82 , and 162 vs. $141 \mathrm{~mL} / \mathrm{g}$ OM at 12, 24, and $48 \mathrm{~h}$ incubation, $p>0.05$ ). For a clearer interpretation of results, these are presented separately for NP and GR in Figures 1 and 2. Among NP substrates (Figure 1), the highest volume of gas was recorded with 
BP from 8 h onwards, whereas SH did not show any differences as compared with DA and PK until $24 \mathrm{~h}$, but it was higher thereafter. Throughout the incubation, $\mathrm{OH}$ and BS had the lowest volume of gas production, but, at 36 and $48 \mathrm{~h}$, gas from BS was higher than $\mathrm{OH}(p<0.05)$. Substrates ranked similarly when they were incubated ground (Figure 2), with BP producing the highest gas volume from 6 to $48 \mathrm{~h}$ incubation and SH fermenting at a higher extent than DA and PK from, respectively, 12 and $24 \mathrm{~h}$ onwards $(p<0.05)$. Again, $\mathrm{OH}$ and $\mathrm{BS}$ recorded the lowest gas volumes along the whole incubation period.

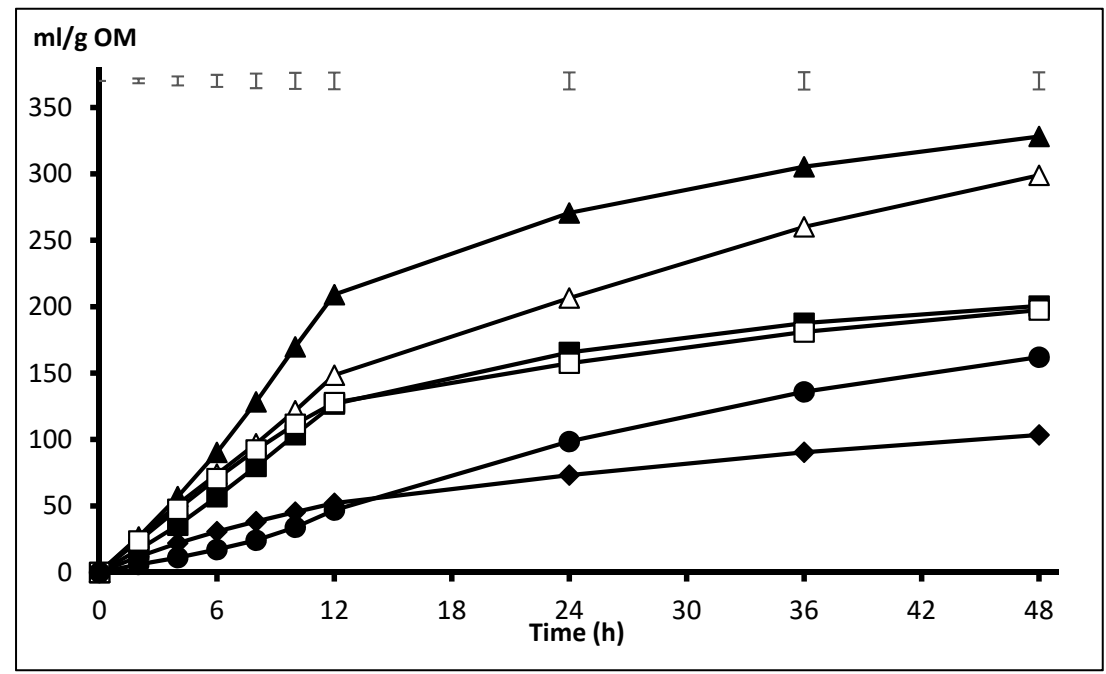

Figure 1. Pattern of gas production from the fibrous substrates $(\mathrm{SH} \triangle, \mathrm{BP} \mathbf{\Lambda}, \mathrm{PK} \mathbf{\square}, \mathrm{OH} \bullet, \mathrm{DA} \square$, and BS •) incubated non-processed (NP). Upper bars show standard error of means $(n=4)$.

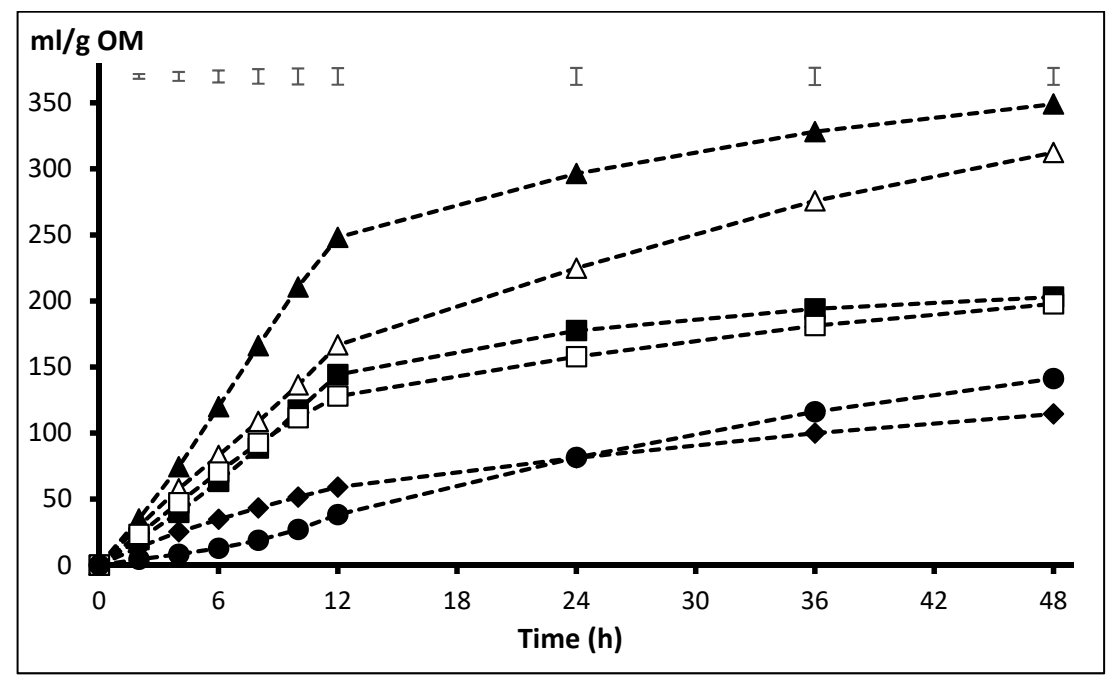

Figure 2. Pattern of gas production from the fibrous substrates ( $\mathrm{SH} \triangle, \mathrm{BP} \mathbf{\Delta}, \mathrm{PK} \mathbf{\square}, \mathrm{OH} \bullet, \mathrm{DA} \square$, and BS •) incubated ground (GR). Upper bars show standard error of means $(n=4)$.

When the accumulated methane production was considered (expressed as mmol/g OM of incubated substrate), results in the first half of the incubation period were higher in GR vs. NP ( 0.45 vs. 0.38 from 0 to $12 \mathrm{~h}, p<0.001$, and 0.79 vs. 0.75 from 12 to $24 \mathrm{~h}, p<0.022)$, but differences disappeared thereafter. Since a significant effect of the interaction presentation $x$ substrate was detected at any time interval $(p<0.01)$, substrate comparison is shown separately for NP (Figure 3a) and GR (Figure 3b) presentation forms. Among NP substrates, methane production with BP was the highest up to $24 \mathrm{~h}$ incubation, but differences between this and $\mathrm{SH}$ disappeared thereafter. Methane became higher with $\mathrm{SH}$ than $\mathrm{PK}, \mathrm{DA}$, and BS from $24 \mathrm{~h}$ onwards, and $\mathrm{OH}$ recorded the lowest methane production throughout 
the incubation period, although it did not differ with BS at $12 \mathrm{~h}$. When incubated GR (Figure 3b), methane from BP was also the highest up to $24 \mathrm{~h}$, but that from SH proportionally increased thereafter and became higher than BP at $48 \mathrm{~h}$. At all incubation times, methane production was also higher with $\mathrm{SH}$ than $\mathrm{PK}, \mathrm{DA}, \mathrm{BS}$, and $\mathrm{OH}$. Again, $\mathrm{OH}$ recorded the lowest methane production, except that it did not differ with BS at 12 and $24 \mathrm{~h}$. Methane proportion in total gas produced is shown in Table 2. In the first $12 \mathrm{~h}$, no effect of the presentation form was detected, but $\mathrm{OH}$ and BS recorded the overall substrate lowest proportion $(p<0.05)$. From 12 to 24 h no differences were recorded among NP substrates, whereas in GR form methane proportion was higher with SH and DA than PK and BS, and BP was also higher than BS (effect of the interaction presentation $\mathrm{x}$ substrate, $p<0.013$ ). From 24 to $36 \mathrm{~h}$, PK recorded the lowest methane proportion, and with BS it was lower than $\mathrm{SH}(p<0.05)$. Again, substrate response differed between presentation forms in the last fermentation interval ( 36 to $48 \mathrm{~h}$, $p=0.025)$, and PK rendered less methane than $\mathrm{OH}$ and DA when NP but it resulted lower than the other substrates, except for BS, when GR $(p<0.05)$.

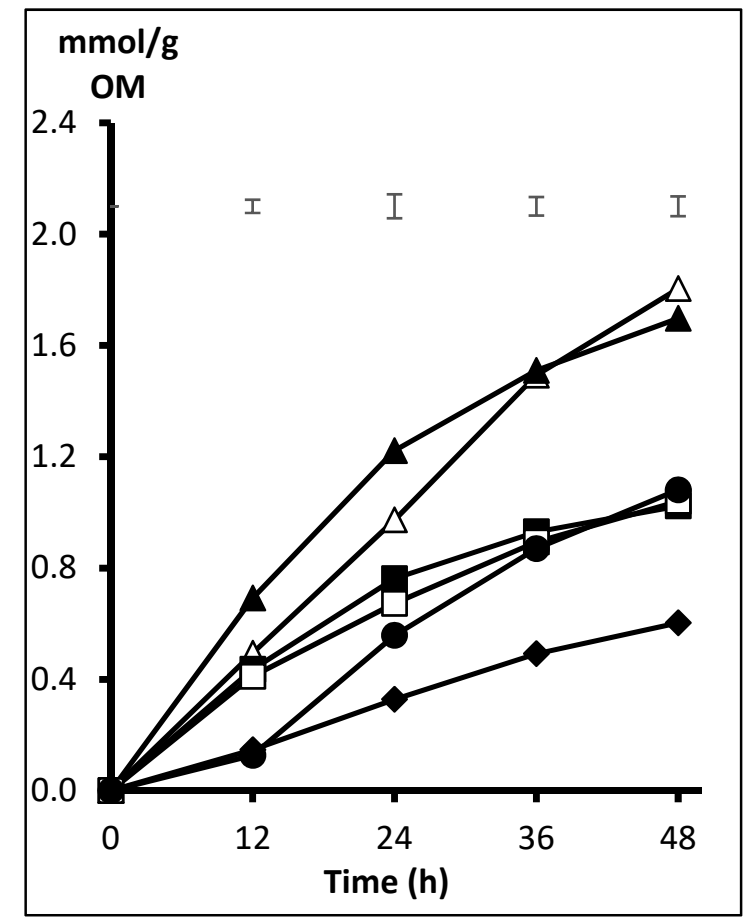

(a)

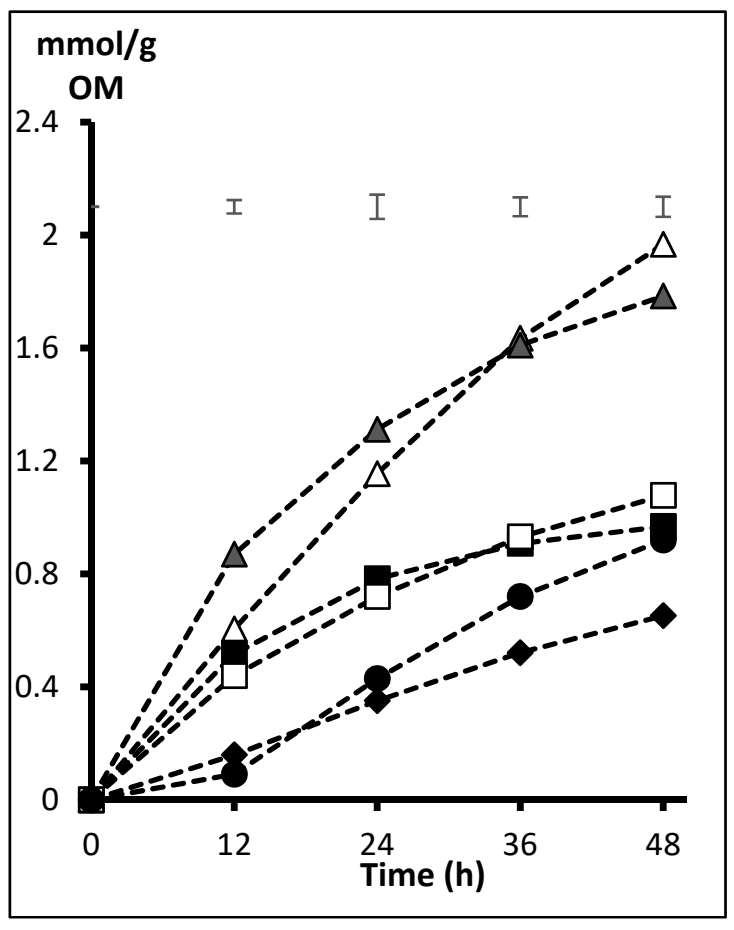

(b)

Figure 3. Average pattern of methane production ( $\mathrm{mmol} / \mathrm{g} \mathrm{OM})$ from fibrous substrates $(\mathrm{SH} \triangle, \mathrm{BP} \mathbf{\Delta}$, $\mathrm{PK} \mathbf{\square}, \mathrm{OH} \bullet, \mathrm{DA} \square$, and BS •) incubated non-processed (NP, (a)) or ground (GR, (b)). Upper bars show standard error of means $(n=4)$

The proportion of OMd after $48 \mathrm{~h}$ incubation was higher when presented ground (0.628 vs. 0.605 for GR and NP, $p=0.029$ ). Among substrates (Table 2), overall OMd means of BP and SH were the highest, whereas $\mathrm{OH}$ was the lowest, even below BS $(p<0.05)$. The effect of the interaction presentation form $x$ substrate on OMd was not significant $(p>0.10)$.

Tables 3 and 4 show no differences between the presentation forms in total VFA concentration nor in molar VFA proportions, at either 12 or $24 \mathrm{~h}$ incubation. At $12 \mathrm{~h}$, fermentation of BP produced a higher total VFA concentration than the other substrates $(p<0.05)$ except for DA. Additionally, BP showed the highest proportion of propionate and lowest proportion of branched-chain volatile fatty acids (BCVFA, sum of isobutyrate and isovalerate), whereas PK showed the highest proportion of butyrate at the expense of propionate which was lower than $\mathrm{BP}$ and $\mathrm{SH}$, and acetate which was lower than DA. At $24 \mathrm{~h}$ incubation, the highest total VFA concentration was observed for BP and SH. Again, 
PK showed the highest butyrate proportion, whereas those of acetate and propionate were lower than $\mathrm{BS}, \mathrm{SH}$, and BP, and lower than BP and DA, respectively. In addition, propionate proportion was higher with $\mathrm{BP}$ than $\mathrm{BS}$ and $\mathrm{OH}$, and that of butyrate was lower with $\mathrm{BS}, \mathrm{SH}$, and BP than with that of $\mathrm{OH}$. The effect of the interaction presentation form $\times$ substrate was not significant on any parameter at either 12 or $24 \mathrm{~h}(p>0.05)$.

Table 2. Methane concentration ( $\mathrm{mL} / \mathrm{mL}$ total gas) at different time intervals, from fermentation of fibrous substrates, non-processed, or in ground form, and organic matter disappearance (OMd, g/g).

\begin{tabular}{cccccc}
\hline Substrate & $\mathbf{0 - 1 2} \mathbf{h}$ & $\mathbf{1 2 - 2 4} \mathbf{h}$ & $\mathbf{2 4 - 3 6 \mathbf { h }}$ & $\mathbf{3 6 - 4 8} \mathbf{h}$ & $\mathbf{O M d}$ \\
\hline $\begin{array}{c}\text { Non-processed } \\
\text { (NP) }\end{array}$ & 0.075 & 0.187 & 0.218 & $0.179^{\mathrm{ab}}$ & 0.827 \\
SH & & & & & \\
BP & 0.074 & 0.194 & 0.187 & $0.177^{\mathrm{ab}}$ & 0.884 \\
PK & 0.076 & 0.188 & 0.172 & $0.162^{\mathrm{b}}$ & 0.573 \\
OH & 0.062 & 0.198 & 0.207 & $0.192^{\mathrm{a}}$ & 0.237 \\
DA & 0.072 & 0.198 & 0.208 & $0.198^{\mathrm{a}}$ & 0.622 \\
BS & 0.060 & 0.186 & 0.188 & $0.182^{\mathrm{ab}}$ & 0.486 \\
Ground (GR) & & & & & \\
SH & 0.081 & $0.212^{\mathrm{w}}$ & 0.211 & $0.203^{\mathrm{w}}$ & 0.849 \\
BP & 0.078 & $0.206^{\mathrm{wx}}$ & 0.209 & $0.187^{\mathrm{wx}}$ & 0.883 \\
PK & 0.079 & $0.180^{\mathrm{xy}}$ & 0.167 & $0.151^{\mathrm{y}}$ & 0.645 \\
OH & 0.060 & $0.195^{\mathrm{wxy}}$ & 0.203 & $0.204^{\mathrm{w}}$ & 0.283 \\
DA & 0.077 & $0.209^{\mathrm{w}}$ & 0.202 & $0.199^{\mathrm{wx}}$ & 0.626 \\
BS & 0.052 & $0.174^{\mathrm{y}}$ & 0.189 & $0.177^{\mathrm{xy}}$ & 0.481 \\
SEM & 0.0040 & 0.0053 & 0.0058 & 0.0060 & 0.0174 \\
\hline $\begin{array}{c}\text { P-value } \\
\text { Presentation }\end{array}$ & 0.52 & 0.18 & 0.90 & 0.060 & 0.029 \\
Substrate & $<0.001$ & $<0.001$ & $<0.001$ & $<0.001$ & $<0.001$ \\
$\mathrm{P} \times$ S interaction & 0.51 & 0.013 & 0.15 & 0.025 & 0.20 \\
\hline
\end{tabular}

$\mathrm{SH}$, soybean hulls; BP, sugarbeet pulp; PK, palm kernel meal; OH, oat hulls; DA, dehydrated alfalfa meal; BS, barley straw. Means in a column with different superscripts for NP $\left(^{\mathrm{a}, \mathrm{b}}\right)$ or GR $\left({ }^{\mathrm{w}, x, y}\right)$ differ $(p<0.05)$. SEM, standard error of means.

Table 3. Average of total volatile fatty acids concentration (VFA, mM) and molar VFA proportions $(\mathrm{mmol} / \mathrm{mmol})$ for the main effects' presentation form and substrate, recorded at $12 \mathrm{~h}$ of incubation.

\begin{tabular}{ccccccc}
\hline Effect & VFA & Acetate & Propionate & Butyrate & Valerate & BCVFA \\
\hline Presentation & $44.8^{2}$ & 0.596 & 0.190 & 0.164 & 0.010 & 0.039 \\
NP & 46.5 & 0.606 & 0.188 & 0.159 & 0.010 & 0.037 \\
GR & 2.54 & 0.0132 & 0.0050 & 0.0067 & 0.0006 & 0.0020 \\
SEM & & & & & & \\
Substrate & $44.5^{\mathrm{b}}$ & $0.586^{\mathrm{ab}}$ & $0.210^{\mathrm{ab}}$ & $0.147^{\mathrm{bc}}$ & $0.013^{\mathrm{a}}$ & $0.044^{\mathrm{abc}}$ \\
SH & $68.5^{\mathrm{a}}$ & $0.619^{\mathrm{ab}}$ & $0.238^{\mathrm{a}}$ & $0.123^{\mathrm{c}}$ & $0.007^{\mathrm{b}}$ & $0.014^{\mathrm{d}}$ \\
$\mathrm{BP}$ & $47.4^{\mathrm{b}}$ & $0.531^{\mathrm{b}}$ & $0.169^{\mathrm{c}}$ & $0.254^{\mathrm{a}}$ & $0.011^{\mathrm{a}}$ & $0.035^{\mathrm{bc}}$ \\
PK & $30.5^{\mathrm{b}}$ & $0.595^{\mathrm{ab}}$ & $0.161^{\mathrm{c}}$ & $0.185^{\mathrm{b}}$ & $0.010^{\mathrm{ab}}$ & $0.050^{\mathrm{ab}}$ \\
OH & $49.0^{\mathrm{ab}}$ & $0.657^{\mathrm{a}}$ & $0.177^{\mathrm{bc}}$ & $0.126^{\mathrm{c}}$ & $0.009^{\mathrm{ab}}$ & $0.031^{\mathrm{c}}$ \\
DA & $29.0^{\mathrm{b}}$ & $0.626^{\mathrm{ab}}$ & $0.167^{\mathrm{c}}$ & $0.137^{\mathrm{bc}}$ & $0.012^{\mathrm{a}}$ & $0.059^{\mathrm{a}}$ \\
BS & 4.40 & 0.0164 & 0.0087 & 0.0119 & 0.0010 & 0.0035 \\
SEM & & & & & & \\
\hline$p$-value & 0.40 & 0.70 & 0.70 & 0.49 & 0.87 & 0.25 \\
Presentation & $<0.001$ & 0.015 & $<0.001$ & $<0.001$ & 0.002 & $<0.001$ \\
Substrate & 0.57 & 0.93 & 0.86 & 0.92 & 0.82 & 0.54 \\
$\mathrm{P} \times$ S interaction &
\end{tabular}

BCVFA, branched-chain volatile fatty acids (isobutyrate + isovalerate); NP, non-processed; GR, ground; SH, soybean hulls; BP, sugarbeet pulp; PK, palm kernel meal; OH, oat hulls; DA, dehydrated alfalfa meal; BS, barley straw. ${ }^{a, b, c}$ Means in a column with different superscripts differ $(p<0.05)$. SEM, standard error of means. 
Table 4. Average of total volatile fatty acids concentration (VFA, mM) and molar VFA proportions $(\mathrm{mmol} / \mathrm{mmol})$ for the main effects' presentation form and substrate, recorded at $24 \mathrm{~h}$ of incubation.

\begin{tabular}{|c|c|c|c|c|c|c|}
\hline Effect & VFA & Acetate & Propionate & Butyrate & Valerate & BCVFA \\
\hline $\begin{array}{c}\text { Presentation } \\
\text { NP }\end{array}$ & 61.0 & 0.606 & 0.178 & 0.159 & 0.014 & 0.044 \\
\hline GR & 68.1 & 0.613 & 0.177 & 0.157 & 0.014 & 0.040 \\
\hline SEM & 5.24 & 0.0142 & 0.0054 & 0.0066 & 0.0008 & 0.0025 \\
\hline \multicolumn{7}{|l|}{ Substrate } \\
\hline $\mathrm{SH}$ & $92.9^{\mathrm{a}}$ & $0.663^{\mathrm{a}}$ & $0.173^{a b c}$ & $0.112^{c}$ & $0.014^{\mathrm{ab}}$ & $0.038^{a b}$ \\
\hline $\mathrm{BP}$ & $100.7^{\mathrm{a}}$ & $0.632^{\mathrm{a}}$ & $0.208^{a}$ & $0.125^{c}$ & $0.010^{b}$ & $0.025^{b}$ \\
\hline PK & $49.4^{\mathrm{b}}$ & $0.505^{b}$ & $0.157^{c}$ & $0.278^{a}$ & $0.017^{\mathrm{a}}$ & $0.042^{\mathrm{ab}}$ \\
\hline $\mathrm{OH}$ & $34.9^{b}$ & $0.583^{\mathrm{ab}}$ & $0.162^{b c}$ & $0.184^{b}$ & $0.015^{a b}$ & $0.056^{\mathrm{a}}$ \\
\hline DA & $50.5^{\mathrm{b}}$ & $0.587^{\mathrm{ab}}$ & $0.198^{a b}$ & $0.149^{b c}$ & $0.017^{\mathrm{a}}$ & $0.049^{a}$ \\
\hline BS & $51.4^{b}$ & $0.678^{a}$ & $0.163^{b c}$ & $0.105^{c}$ & $0.011^{b}$ & $0.043^{\mathrm{ab}}$ \\
\hline SEM & 8.89 & 0.0240 & 0.0092 & 0.0112 & 0.0014 & 0.0043 \\
\hline \multicolumn{7}{|l|}{$p$-value } \\
\hline Presentation & 0.42 & 0.81 & 0.95 & 0.83 & 0.95 & 0.32 \\
\hline Substrate & 0.003 & $<0.001$ & 0.001 & $<0.001$ & 0.005 & 0.001 \\
\hline $\mathrm{P} \times \mathrm{S}$ interaction & 0.46 & 0.54 & 0.60 & 0.83 & 0.19 & 0.63 \\
\hline
\end{tabular}

$\mathrm{a}, \mathrm{b}, \mathrm{c}$ Means in a column with different superscripts differ $(p<0.05)$. SEM, standard error of means; BCVFA, branched-chain volatile fatty acids (isobutyrate + isovalerate); NP, non-processed; GR, ground; SH, soybean hulls; $\mathrm{BP}$, sugarbeet pulp; $\mathrm{PK}$, palm kernel meal; $\mathrm{OH}$, oat hulls; DA, dehydrated alfalfa meal; BS, barley straw.

\section{Discussion}

\subsection{Effect of Particle Size}

The proportion and composition of the fibrous fraction of feeds determines its nutritive value, but its physical presentation form that can determine its rate of intake and modulate the digesta rate of passage $[13,19]$ must also be considered. However, for forages, particle size has been generally measured into large categories (more than $19 \mathrm{~mm}$, from 8 to $19 \mathrm{~mm}$, between 1.18 and $8 \mathrm{~mm}$, and less than $1.18 \mathrm{~mm}$ ) which do not allow for characterizing most non-forage fibrous feeds as such intervals do not fit with their smaller sizes. Thus, Iraia et al. [12] described barley straw, soybean hulls, beet pulp, and whole cotton seeds as having 0.64 to 0.94 of particles smaller than $8 \mathrm{~mm}$, whereas their average particle size was 1.5 to $3.0 \mathrm{~mm}$. In our study, the average particle size ranked substrates in three categories, i.e., over $5 \mathrm{~mm}(\mathrm{OH})$, from 1.7 to $1.9 \mathrm{~mm}(\mathrm{BP}$ and $\mathrm{SH})$, and below $1.2 \mathrm{~mm}(\mathrm{PK}, \mathrm{DA})$, whereas BS was homogenized by manually cutting to approximately $20 \mathrm{~mm}$.

An in vitro approach does not allow for the study of the effect of presentation form on feeding behavior of ruminants assumed as the proportion of fiber that stimulates chewing and salivation, rumination, and ruminal motility that is referred to as effective fiber (peNDF [27]). Thus, this work is restricted to the evaluation of a potential effect of particle size on fermentation, determined by the physical availability of feed particles to microbial attack. In any case, if peNDF of substrates in their non-processed form is estimated from the amount of NDF and the proportion of particles over $1.2 \mathrm{~mm}$ size [9], it should be $0.65,0.35,0.35,0.28$, and 0.05 for $\mathrm{OH}, \mathrm{SH}, \mathrm{BP}, \mathrm{PK}$, and DA, respectively. By comparison, peNDF for BS estimated from its NDF content and considering a physical effectiveness factor (pef) of 0.80 [9] should give a value of 0.61 , close to that of $\mathrm{OH}$ and higher to the other non-forage substrates. It is worth considering that a level of 0.07 to 0.10 of peNDF in feed DM has been recommended for intensively reared beef cattle $(8 \%-10 \%$ forage, in DM basis) to maintain rumen $\mathrm{pH}$ above 5.7 [28], although it is often below in commercial practice [27].

According to Zebeli et al. [29], large feed particle size could increase resistance to microbial attachment and degradation. In our study, grinding of substrates promoted a higher rate of fermentation estimated from gas production, resulting in a 0.12 increase at $6 \mathrm{~h}$ fermentation, which was reduced afterwards to 0.09 and 0.05 after 12 and $24 \mathrm{~h}$ incubation, and to only 0.02 after $48 \mathrm{~h}$. Similarly, 
a higher OMd $(p<0.05)$ was observed with GR substrates, although increased losses of substrate during filtration because of grinding to $1 \mathrm{~mm}$ cannot be discarded. The positive effect of grinding on fermentation was not manifested as a clear response on total VFA, although the differences were of a similar magnitude ( 0.12 times higher for GR than NP at $24 \mathrm{~h}$ incubation), partly because of the high magnitude of the error term (coefficient of variation 0.39 ). The increase in gas volume that was numerically appreciable for $\mathrm{SH}, \mathrm{PK}$, and $\mathrm{OH}(0.11$ to 0,12 higher in GR than NP form at $12 \mathrm{~h})$, only resulted significant for BP $(p<0.05)$. Considering the high fermentability of BP [30], reducing particle size from 1.77 to $1.00 \mathrm{~mm}$ should increase nutrient accessibility. No effect of grinding was detected on DA, which was expected considering that the average particle size of this substrate was below the size of grinding. However, in the case of BS, a numerically $(p>0.10)$ higher fermentation was observed when incubated NP, with gas volumes 0.07 and 0.21 higher than GR at 12 and $24 \mathrm{~h}$, respectively, which contrasts with the results of coarse and fine grinding roughages observed by Menke and Steingass [16]. Grinding straw could release monophenolic compounds such as ferulic and p-coumaric acids, which can depress fibrolytic microbial activity [31,32], but this effect was of minor magnitude. In any case, substrates ranked the same despite their presentation form, and therefore it seems evident that grinding to a standard size of $1 \mathrm{~mm}$ is a good alternative for the in vitro study and comparison of the fermentation pattern of feeds $[16,20]$.

Alternatively, the fermentation of non-processed substrates was slightly more efficient than when incubated ground, as the methane proportion in the gas produced tended $(p=0.06)$ to be higher in GR from 36 to $48 \mathrm{~h}$. This should be against the lower methane production expected when feeds are given finely ground as compared with chopped $[33,34]$. However, the heterogeneous particle size of the non-processed substrates in relation to their ground form, together with the potential responses in their rate of passage [35] that cannot be considered in vitro, could bias the response. In any case, the lack of differences in the first stages of fermentation indicates that this was not a major issue, and when expressed as accumulated methane $(\mathrm{mmol} / \mathrm{g} \mathrm{OM})$ the reduction of particle size increased methane production in the first $24 \mathrm{~h}$ of fermentation but only for $\mathrm{BP}$ at $12 \mathrm{~h}$ and $\mathrm{SH}$ at $24 \mathrm{~h}$ (significant interaction presentation $\times$ substrate, $p<0.01$ ).

Despite the range of particle sizes studied, it is worthwhile to consider that Zebeli et al. [14] did not observe differences in VFA concentration in corn silage diets with different proportions of particles below $8 \mathrm{~mm}$; however, they reported a higher fibrolytic enzyme activity as particle size diminished, which agrees with the higher gas production observed in the present work. Yang and Beauchemin [36] did not observe differences in NDF rumen disappearance of corn silage between particles of 5,11 , and $19 \mathrm{~mm}$.

\subsection{Effect of the Type of Substrate}

The substrate that promoted a higher and faster gas production was BP, in response to the high fermentability of its cell wall [30] and the high proportion of soluble fiber, composed by pectins and rapidly fermentable oligosaccharides [37,38]. Afterwards, differences with $\mathrm{SH}$ were progressively reduced, whereas that with PK and DA were maintained. This fermentation pattern was supported by total VFA production. The slower fermentation of $\mathrm{SH}$ as compared with BP can be explained by its higher NDF proportion, but also by its greater $\mathrm{CP}$ fraction. A negative correlation of either feed CP or ammonia released from it and gas production have been reported [39,40], because of both the sequestering of $\mathrm{CO}_{2}$ by the released ammonia and the lower fermentable energy of protein as compared with carbohydrates. In this sense, Cone and van Gelder [41] observed that gas production diminishes by $2.5 \mathrm{~mL}$ for every percentage unit of $\mathrm{CP}$. Thus, comparing $\mathrm{CP}$ of $\mathrm{BP}$ and SH should justify around $40 \mathrm{~mL}$ lower gas in $\mathrm{SH}$, which is 0.29 to 0.38 of gas differences between these substrates at $12 \mathrm{~h}$ incubation. Thereafter, the reduction of differences was possibly due to the exhaustion of both soluble fiber in the case of BP and of protein for SH. The fermentation of both BP and SH promoted a high molar proportion of acetate and propionate $[8,42]$ at the expense of butyrate as compared with the other substrates. 
Almost two-thirds of the gas volume from PK and DA was produced during the first $12 \mathrm{~h}$ incubation, as in the case of $\mathrm{SH}$ mentioned above, the moderately high proportion of CP in both PK and DA in relation to other studied substrates such as BP, BS, and $\mathrm{OH}$ could also underestimate their gas production [41], although at a lower extent than for $\mathrm{SH}$. In addition, the high proportion of ether extract in PK can also affect the potential of microbial fermentation, initially in a positive sense because of the rapid use of glycerol from hydrolysis of triglycerides but negatively thereafter by the inhibitory effect of fatty acids on microbial fermentation [43]. The use of glycerol from lipolysis is supported by the high proportion of butyrate and valerate at the expense of acetate, as it has been previously reported [44].

The lowest gas production pattern was observed with both $\mathrm{BS}$ and $\mathrm{OH}$, and is explained by their NDF proportion over $760 \mathrm{mg} / \mathrm{g}$. In contrast to other substrates, the highest proportion of gas produced from BS occurred from 12 to $48 \mathrm{~h}$, where 0.72 of total gas volume was released. Similar proportions (0.83 and 0.60 , respectively) have been previously recorded $[20,45]$.

In general, the proportion of methane in the total gas produced agreed with the rate and extent of fermentation of substrates. Thus, those that were highly fermented in the first part of incubation (BP, SH, PK, and DA) showed a high proportion of methane in the first $12 \mathrm{~h}$ of incubation. The high methane proportion is in contrast with the higher propionate proportion with these substrates, since a negative relationship has been observed among them [46]. In contrast, fermentation of $\mathrm{OH}$, a high fiber, low fermented substrate was less efficient [18] and reached a higher methane proportion in the last part of incubation. In the case of PK, a low methane proportion can be expected because of the effect of its high proportion of ether extract [47]. Because of this inconsistent response among substrates in methane proportion, total methane production per unit of incubated substrate was more dependent on total magnitude of fermentation rather than on qualitative changes in the fermentation pattern. In this regard, no major differences were detected between BS and the other substrates, despite Salami et al. [17] estimated a reduced enteric methane emission when the proportion of non-forage by-products increased. However, despite substrates heterogeneity, a significant correlation was observed between the methane produced per unit of incubated substrate at 12 and $24 \mathrm{~h}$ and the NDF content of feeds $(R=0.72$ and 0.59$)$, although this is of limited value considering the scarce number of substrates tested.

\section{Conclusions}

The particle size of fibrous substrates has a major impact on the extent of their rumen microbial fermentation but not on its rate, and therefore both presentations classify the substrates in the same order. Therefore, their different response in digestive utilization under practical conditions is instead related to factors associated with animal feeding behavior, which is out of the scope of this in vitro work that modulates rumen $\mathrm{pH}$ and rate of passage. Methodologically, grinding feeds to $1 \mathrm{~mm}$ particle size is a valid standardization in in vitro incubation trials, which does not alter substrates comparison. Fermentation of non-forage fibrous substrates highlights the effects of the proportion and composition of their cell wall fraction. However, other non-fibrous components, such as the levels of protein and fat, can also modulate the response. Methane production as an index of fermentation efficiency did not show major differences between feed presentation forms, nor non-forage substrates as compared with straw and was more related with the magnitude of fermentation than with qualitative changes in fermentation.

Author Contributions: Conceptualization, M.F.; methodology, M.F., I.R.O., and Z.A.; software, I.R.O. and Z.A.; formal analysis, I.R.O. and Z.A.; investigation, I.R.O., Z.A., and M.F.; resources, M.F.; writing一original draft preparation, I.R.O.; writing-review and editing, M.F.; supervision, M.F.; project administration, M.F.; funding acquisition, M.F. All authors have read and agreed to the published version of the manuscript.

Funding: Work financed by the company INZAR (contract OTRI 2018/0366), with the participation of the Department of Industry and Innovation of the Government of Aragón and the European Social Fund.

Acknowledgments: Sincere appreciation to the lab team for their support in laboratory work. 
Conflicts of Interest: There were no conflicts of interests. The funders had no role in the design of the study; in the collection, analyses, or interpretation of data; in the writing of the manuscript, or in the decision to publish the results.

\section{References}

1. Devant, M.; Ferret, A.; Gasa, J.; Calsamiglia, S.; Casals, R. Effects of protein concentration and degradability on performance, ruminal fermentation and nitrogen metabolism in rapidly growing heifers fed high-concentrate diets from 100 to $230 \mathrm{~kg}$ body weight. J. Anim. Sci. 2000, 78, 1667-1676. [CrossRef]

2. Faleiro, A.G.; González, L.A.; Blanch, M.; Cavini, S.; Castells, L.; Ruiz de la Torre, J.L.; Manteca, X.; Calsamiglia, S.; Ferret, A. Performance, ruminal change, behaviour and welfare of growing heifers fed a concentrate diet with or without barley straw. Animal 2011, 5, 294-303. [CrossRef]

3. Gimeno, A.; Al-Alami, A.; Abecia, L.; de Vega, A.; Fondevila, M.; Castrillo, C. Effect of type (barley vs. maize) and processing (grinding vs. dry rolling) of cereal on ruminal fermentation and microbiota of beef calves during the early fattening period. Anim. Feed Sci. Technol. 2015, 199, 113-126. [CrossRef]

4. Owens, F.N.; Secrist, D.S.; Hill, W.J.; Gill, D.R. Acidosis in cattle: A review. J. Anim. Sci. 1998, 76, $275-286$. [CrossRef] [PubMed]

5. Armentano, L.; Pereira, M. Measuring the effectiveness of fiber by animal response trials. J. Dairy Sci. 1997, 80, 1416-1425. [CrossRef]

6. Grant, R.J. Interactions among forages and nonforage fiber sources. J. Dairy Sci. 1997, 80, 1438-1446. [CrossRef]

7. DePeeters, E.J.; Fadel, J.G.; Arosemena, A. Digestion kinetics of neutral detergent fiber and chemical composition within some selected by-product feedstuffs. Anim. Feed Sci. Technol. 1997, 67, 127-140. [CrossRef]

8. Hsu, J.T.; Faulkner, D.B.; Garleb, K.A.; Barclay, G.C.; Fahey, G.C., Jr.; Berger, L.L. Evaluation of corn fiber, cottonseed hulls, oat hulls and soybean hulls as roughage sources for ruminants. J. Anim. Sci. 1987, 65, 244-255. [CrossRef] [PubMed]

9. Mertens, D.R. Creating a system for meeting the fiber requirements of dairy cows. J. Dairy Sci. 1997, 80, 1463-1481. [CrossRef]

10. Yang, W.Z.; Beauchemin, K.A. Altering physically effective fiber intake through forage proportion and particle length: Chewing and ruminal pH. J. Dairy Sci. 2007, 90, 2826-2838. [CrossRef]

11. Bradford, B.J.; Mullins, C.R. Strategies for promoting productivity and health of dairy cattle by feeding nonforage fiber sources. J. Dairy Sci. 2012, 95, 4735-4746. [CrossRef]

12. Iraia, S.P.; Ruiz de la Torre, J.L.; Rodríguez-Prado, M.; Calsamiglia, S.; Manteca, X.; Ferret, A. Feed intake, ruminal fermentation and animal behaviour of beef heifers fed forage free diets containing nonforage fiber sources. J. Anim. Sci. 2013, 91, 3827-3835. [CrossRef]

13. Tafaj, M.; Zebeli, Q.; Baes, C.; Steingass, H.; Drochner, W. A meta-analysis examining effects of particle size of total mixed rations on intake, rumen digestion and milk production in high yielding dairy cows in early lactation. Anim. Feed Sci. Technol. 2007, 138, 137-161. [CrossRef]

14. Zebeli, Q.; Tafaj, M.; Junck, B.; Olschlager, V.; Ametaj, B.N.; Drochner, W. Evaluation of the response of ruminal fermentation and activities of non-starch polysaccharide-degrading enzymes to particle length of corn silage in dairy cows. J. Dairy Sci. 2008, 91, 2388-2398. [CrossRef] [PubMed]

15. Shain, D.H.; Stock, R.A.; Klopfenstein, T.J.; Herold, D.W. The effect of forage source and particle size on finishing yearling steer performance and ruminal metabolism. J. Anim. Sci. 1999, 77, 1082-1092. [CrossRef]

16. Menke, K.H.; Steingass, H. Estimation of the energy feed value obtained from chemical analysis and in vitro gas production using rumen fluid. Anim. Res. Develop. 1988, 28, 7-55.

17. Salami, S.A.; Luciano, G.; O’Grady, M.N.; Biondi, L.; Newbold, C.J.; Kerry, J.P.; Priolo, A. Sustainability of feeding plant by-products: A review of the implications for ruminant meat production. Anim. Feed Sci. Technol. 2019, 251, 37-55. [CrossRef]

18. Knapp, J.R.; Laur, G.L.; Vadas, P.A.; Weis, W.P.; Tricarico, J.M. Invited review: Enteric methane in dairy cattle production: Quantifying the opportunities and impact of reducing emissions. J. Dairy Sci. 2014, 97, 3231-3261. [CrossRef] [PubMed] 
19. Firkins, J.F. Effects of feeding nonforage fiber sources on site of fiber digestion. J. Dairy Sci. 1997, 80, $1426-1437$. [CrossRef]

20. Mould, F.L.; Kliem, K.E.; Morgan, R.; Mauricio, R.M. In vitro microbial inoculum: A review of its function and properties. Anim. Feed Sci. Technol. 2005, 123-124, 31-50. [CrossRef]

21. Theodorou, M.K.; Williams, B.A.; Dhanoa, M.S.; McAllan, A.B.; France, J. A simple gas production method using a pressure transducer to determine the fermentation kinetics of ruminant feeds. Anim. Feed Sci. Technol. 1994, 48, 185-197. [CrossRef]

22. Amanzougarene, Z.; Fondevila, M. Fitting of $\mathrm{pH}$ conditions for the study of concentrate feeds fermentation by the in vitro gas production technique. Anim. Prod. Sci. 2018, 58, 1751-1757. [CrossRef]

23. AOAC. Official Methods of Analysis, 18th ed.; Horwitz, W., Latimer, G.W., Eds.; Association of Official Analytical Chemists: Gaithersburg, MD, USA, 2005.

24. Mertens, D.R. Gravimetric determination of amylase-treated neutral detergent fiber in feeds with refluxing in beakers or crucibles: Collaborative study. J. AOAC Int. 2002, 85, 1217-1240. [PubMed]

25. Robertson, J.B.; Van Soest, P.J. The detergent system of analysis and its application to human foods. In The Analysis of Dietary Fiber in Foods; James, W.P.T., Theander, O., Eds.; Marcel Dekker: New York, NY, USA, 1981; pp. 123-158.

26. Analytical Software. Statistix 10 for Windows; Analytical Software: Tallahasee, FL, USA, 2010.

27. National Academy of Sciences, Engineering and Medicine. Nutrient Requirements of Beef Cattle, 9th ed.; The National Academies Press: Washington, DC, USA, 2016.

28. Fox, D.G.; Tedeschi, L.O. Application of physically effective fiber in diets for feedlot cattle. In Proceedings of the Plains Nutrition Council Spring Conference, San Antonio, TX, USA, 25-26 April 2002; pp. 67-81.

29. Zebeli, Q.; Aschenbach, J.R.; Tafaj, M.; Boguhn, J.; Ametaj, B.N.; Drochner, W. Invited review: Role of physically effective fiber and estimation of dietary fiber adequacy in high producing dairy cattle. J. Dairy Sci. 2012, 95, 1041-1056. [CrossRef] [PubMed]

30. Fondevila, M.; Barrios-Urdaneta, A.; Balcells, J.; Castrillo, C. Gas production from straw incubated in vitro with different levels of purified carbohydrates. Anim. Feed Sci. Technol. 2002, 101, 1-15. [CrossRef]

31. Belyea, R.L.; Foster, M.B.; Zinn, G.M. Effect of delignification on in vitro digestion of alfalfa cellulose. J. Dairy Sci. 1983, 66, 1277-1281. [CrossRef]

32. Udén, P. The influence of leaf and stem particle size in vitro and of sample size in sacco on neutral detergent fibre fermentation kinetics. J. Anim. Feed Technol. 1992, 37, 85-97. [CrossRef]

33. Hironaka, R.; Mathison, G.W.; Kerrigan, B.K.; Vlach, I. The effect of pelleting of alfalfa hay on methane production and digestibility by steers. Sci. Total Environ. 1996, 180, 221-227. [CrossRef]

34. Benchaar, C.; Pomar, C.; Chiquette, J. Evaluation of dietary strategies to reduce methane production in ruminants: A modelling approach. Can. J. Anim. Sci. 2001, 81, 563-574. [CrossRef]

35. Okine, E.K.; Mathison, G.W.; Hardin, R.T. Effects of changes in frequency of reticular contractions on fluid and particulate passage rate in cattle. J. Anim. Sci. 1989, 67, 3388-3396. [CrossRef]

36. Yang, W.Z.; Beauchemin, K.A. Effects of physically effective fiber on digestion and milk production by dairy cows fed diets based on corn silage. J. Dairy Sci. 2005, 88, 1090-1098. [CrossRef]

37. Hatfield, R.D.; Weimer, P.J. Degradation characteristics of isolated and in situ cell wall lucerne pectic polysaccharides by mixed ruminal microbes. J. Sci. Food Agric. 1995, 69, 185-196. [CrossRef]

38. Hall, M.B.; Lewis, B.A.; Van Soest, P.J.; Chase, L.E. A simple method for estimation of neutral detergent-soluble fibre. J. Sci. Food Agric. 1997, 74, 441-449. [CrossRef]

39. González Ronquillo, M.; Fondevila, M.; Barrios Urdaneta, A.; Newman, Y. In vitro gas production from buffel grass (Cenchrus ciliaris L.) fermentation in relation to the cutting interval, the level of nitrogen fertilisation and the season of growth. Anim. Feed Sci. Technol. 1998, 72, 19-32. [CrossRef]

40. Getachew, G.; Robinson, P.H.; DePeeters, E.J.; Taylor, S.J. Relationships between chemical composition, dry matter degradation and in vitro gas production of several ruminant feeds. Anim. Feed Sci. Technol. 2004, 111, 57-71. [CrossRef]

41. Cone, J.W.; van Gelder, A.H. Influence of protein fermentation on gas production profiles. Anim. Feed Sci. Technol. 1999, 76, 251-264. [CrossRef]

42. Khan, M.A.; Bach, A.; Weary, D.M.; von Keyserlink, M.A.G. Invited review: Transitioning from milk to solid feed in dairy heifers. J. Dairy Sci. 2016, 99, 885-902. [CrossRef] 
43. Fondevila, M.; Cufré, G.; Nogueira, J.C.M.; Godio, L.; Alcantú, G. Digestion and microbial fermentation of Eragrostis curvula supplemented with tallow. Anim. Sci. 1999, 69, 447-455. [CrossRef]

44. El-Nor, S.A.; AbuGhazaleh, A.A.; Portu, R.B.; Hastings, D.; Khattab, M.S.A. Effect of different levels of glycerol on rumen fermentation and bacteria. Anim. Feed Sci. Technol. 2010, 162, 99-105. [CrossRef]

45. Ribeiro, G.O.; Badhan, A.; Huang, J.; Beauchemin, K.A.; Yang, W.; Wang, Y.; Tsang, A.; McAllister, T.A. New recombinant fibrolytic enzymes for improved in vitro ruminal fiber degradability of barley straw. J. Anim. Sci. 2018, 96, 3928-3942. [CrossRef]

46. Moss, A.; Jouany, J.P.; Newbold, J. Methane production by ruminants: Its contribution to global warming. Ann. Zootech. 2000, 49, 231-253. [CrossRef]

47. Beauchemin, K.A.; Kreuzer, D.M.; O’Mara, F.; McAllister, T.A. Nutritional management for enteric methane abatement: A review. Aust. J. Exp. Agric. 2008, 48, 21-27. [CrossRef]

(C) 2020 by the authors. Licensee MDPI, Basel, Switzerland. This article is an open access article distributed under the terms and conditions of the Creative Commons Attribution (CC BY) license (http://creativecommons.org/licenses/by/4.0/). 